\title{
Ecological Performance: Ethnic Fragmentation versus Governance Quality and Sustainable Development
}

\author{
Efektywność ekologiczna: fragmentacja etniczna \\ a jakość zarządzania i zrównoważony rozwój
}

\author{
Viktor Koziuk*, Yuryi Hayda*, Oleksandr Dluhopolskyi*, \\ Serhii Kozlovskyi** \\ *Ternopil National Economic University \\ **Vasyl' Stus Donetsk National University \\ E-mails: victorkozyuk@ukr.net,haydshn@ua.fm,dlugopolsky77@gmail.com, \\ s.kozlovskyy@donnu.edu.ua
}

\begin{abstract}
The article is devoted to the consideration of the ethical and ecological aspect of the framework conditions for the welfare state formation. The hypothesis of the negative influence of high ethnic fractionalization on the ecological situation in a country that in the classical welfare states is offset by the high efficiency of government through the initiation of the function of balancing the interests of ethnic groups in the transmission buffer mechanism is tested in the paper. The study used correlation and regression analysis tools using the application statistical software package STATISTICA. The hypothesis of an inverse relationship between the degree of heterogeneous society and the ecological quality is empirically substantiated. It is proved that the quality of governance can weaken the inverse relationship between ethnic fractionalization and the ecological situation in the country. In the welfare states, the neutralization factor of ethnic fractionalization by the quality of governance institutions is traced, which testifies to the existence of an institutional transmission buffer mechanism in the relationship between the structure of society and the offer of environmental goods.
\end{abstract}

Key words: ecology, ethnic fractionalization, quality of institutions, government effectiveness, welfare state

\section{Streszczenie}

Artykuł poświęcony jest rozważeniu etycznego i ekologicznego aspektu warunków ramowych tworzenia państwa opiekuńczego. W pracy podjęto się weryfikacji hipotezy negatywnego wpływu wysokiego frakcjonowania etnicznego na sytuację ekologiczną w kraju, które w klasycznych państwach opiekuńczych jest równoważone wysoką przez rządy poprzez uruchomienie funkcji równoważenia interesów grup etnicznych w mechanizmie bufora transmisji. W badaniu wykorzystano narzędzia analizy korelacji i regresji przy użyciu pakietu oprogramowania statystycznego aplikacji STATISTICA. Hipoteza odwrotnej zależności między stopniem heterogenicznego społeczeństwa a jakością ekologiczną jest empirycznie uzasadniona. Udowodniono, że jakość rządzenia może osłabić odwrotny związek między frakcjonowaniem etnicznym a sytuacją ekologiczną w kraju. W państwach opiekuńczych sprawdzono czynnik neutralizacji frakcjonowania etnicznego przez jakość instytucji rządowych, co świadczy o istnieniu instytucjonalnego mechanizmu bufora transmisji pomiędzy strukturą społeczeństwa a ofertą dóbr środowiskowych.

Słowa kluczowe: ekologia, frakcjonowanie etniczne, jakość instytucji, skuteczność rządu, państwo opiekuńcze 


\section{Introduction}

Today, in over 200 countries around the world, there are 5,000 ethnic groups, which means that members of groups with different cultural backgrounds and customs that speak different languages have to live in one state. Despite the fact that such a neighborhood can enrich the culture of all participants, increase tolerance and trust in society, but most researchers tend to link the ethnic heterogeneous society with ethnic conflicts, uprisings and civil wars, the problems of economic growth, as well as the inability of political elites to progressive and effective reforms.

The problem of ethnic and cultural heterogeneity has come to the attention of researchers in recent decades of the twentieth century. Numerous publications of scholars link the ethnic heterogeneous societies with social and economic benefits - high-quality public goods, economic growth, minimal corruption, highquality social capital (Esteban, Ray, 1994; Mauro 1995; Easterly; Levine 1997; Bossert et al. 2011; Fearon, 2003; Dluhopolskyi, Zatonatska et al., 2019; Koziuk et al., 2019). Instead, ethnic fractionalization becomes an obstacle to sustainable development, provokes conflicts and mistrust between members of different groups, reduces the ability to communicate effectively in the political process.

\section{Literature review}

When belonging to ethnic identities becomes important in terms of the political process, they are explained by a variety of concepts, the most famous of which is the theory of resource mobilization, the theory of relative deprivation, and the theory of political possibilities.

The theory of resource mobilization covers several areas:

1) the position of the utilitarian logic of a rational actor (Olson, 1965; Deutsch, 1966), which explains the policy solely individual behavior of individuals. In the context of ethnic fractionalization, this means the commitment of ethnic groups to their own values and goals, as well as attempts to ignore the values and goals of other groups;

2) organizational and entrepreneurial approach (McCarthy, Zald, 1973), which emphasizes the totality of informal preferences that are more or less clearly expressed by the population and turn into requirements with subsequent mobilization of groups. The benefits of different ethnic groups can be controversial, provocative conflicts and struggles for resources, and common, which can be achieved through the formation of coalitions;

3) models of the political process (Tilly, Tarrow, 2006; Davis et al., 2005), which substantiate multifactorial influences on social changes, including due to ethnic and cultural differences. The theory of relative deprivation explains the emergence of political violence by frustration - the discrepancy between expectations of social groups and what they have (Davies, 1962). This is especially true in the face of oppression (explicit or implicit) by the majority group interests of minority ethnic group. The theory of political opportunities emphasizes the existence of a political space (political rights, political channels and political discussions) and the potential of actors (Pieterse, Oldfield, 2002; Carment, James, 2004; Hibbs, 1973). The political space given to this or that ethnic group allows it to exercise its political capabilities to defend its interests in full or in a limited way.

Forms of conflict arising from ethnic fractionalization include coups, interethnic disturbances, civil and hybrid wars, and external military conflicts (Carment, James, 2004). States that have suffered from violent ethnocultural fractionalization and conflicts usually show low levels of socio-economic development, have problems with attracting foreign direct investment, and lose the monopoly of violence, adding to the ranks of fragile states (Collier, Hoeffler, 2004; Rotberg, 2004).

A. Alesina (Alesina et al., 2003) uses the fractionalization category separately for its ethnic, linguistic and religious components. According to research by academics (Alesina et al., 2003; Canning, Fay, 1993; Mauro, 1995), ethnic fractionalization negatively correlates with economic growth and the quality of government, although the negative effects are reduced through education, the development of financial markets and telecommunications, the budget surplus (Easterly, Levine, 1997).

The quality of institutions, social capital, industrialization, urbanization, education and life expectancy are recognized by many scholars as important factors in the survival and sustainability of democracies (Bernhard et al., 2001; Graham et al., 2017; Jacobsen, 2015; Paxton, 2002; Dluhopolskyi, 2012), while the phenomenon of resource curse, property inequality and ethnic heterogeneity, on the contrary, contribute to their fragility (Dunning, 2008; Fish, Kroenig, 2006; Koziuk, Dluhopolskyi, 2018; Boix, Stokes, 2003; Acemoglu, Robinson, 2006; Ahlquist, Wibbels, 2012).

The results of numerous studies (Lipset, 1959; Akhremenko et al., 2018; North et al., 2009; Przeworski, 2005) confirm that economic progress has an impact on democratic institutions in different directions:

1) leads to the emergence of a broad middle class that plays a mitigating role in society (encouraging democratic parties and expelling extremist organizations);

2) promote tolerance and acceptance among citizens in general and politicians, in particular, of 
universalist social norms that promote the emergence of an effective bureaucracy (good governance);

3) raises social standards and quality of life of citizens, minimizing the risk of being treated as a plebistic side by political elites;

4) produces a sense of time in different strata of society (extends their horizons of planning);

5) creates conditions for the development of public organizations that are capable of counterbalancing power;

6) ensures the formation in society such volume of aggregate wealth, so that its moderate redistribution is not critical (staying in the power of one party or another party ceases to fundamentally affect the chances of survival of other influential groups);

7) alleviates the acuteness of the conflict between interest groups on the redistribution of limited resources (range expansion of distribution public policies, concentration of expected redistribution parameters in the zone of moderate values).

The works (Burgess et al., 2011; Alesina et al., 2005; Alesina et al., 2019) analyze the influence of ethnic fractionalization on the decline of the quality of local public goods through the factors affecting corruption, the quality of social capital, and the level of trust. The example of Indonesia (Alesina et al., 2019) established the relationship between ethnic fractionalization and deforestation in the context of the impact of decentralized management of natural resources. Also, Africa's growth tragedy is considered in works (Easterly, Levine, 1997; Canning, Fay, 1993) as an example of low economic productivity due to excessive racial fractionalization.

However, despite the wide range of studies on ethnic fractionalization and its impact on the socio-economic indicators of the development of countries, the relationship problem between ethnic fractionalization and the environmental component of sustainable development - the environmental state remains unexplored.

In scientific paper, three key hypotheses are put forward:

1) there is a cause-and-effect relationship between the ethnic fractionalization of countries and environmental state;

2) this connection is not direct and instant, but is manifested through the transmission buffer mechanism, which is based on the quality and efficiency of state institutions;

3) the negative influence of high ethnic fractionalization on the ecological situation in the country in the welfare states is offset by the high quality and efficiency of governance by initiating the function of balancing the interests of ethno groups in the transmission buffer mechanism.

\section{Research methodology}

To construct the original matrix for cross-country analysis, measurements of ethnic, linguistic and religious fractionalization of countries have been used, which are given in the teamwork of authors led by A. Alesina (Alesina et al., 2003). These measurements are based on identified 650 ethnic groups in 190 countries, 1055 linguistic groups in 201 countries and 294 religions in 215 countries.

As an indicator of the environmental situation in the countries, the Environmental Sustainable Index, developed at the initiative of the public organization Global Leader for Tomorrow, in cooperation with the Center for Environmental Law and Policy of the Yale University (USA) and the Center for International Scientific Information Networks at Columbia University (USA) in 2000, 2001, 2002 and 2005 (Environmental Sustainability Index, 2005). In order to assess the state of the world environment after 2005, the Environmental Performance Index in 2006, 2008, 2010, 2012, 2014, 2016, and 2018 (Environmental Performance Index, 2018) has been included in the output matrix. This index was first developed in 2006 in a pilot project format by the above-mentioned Yale and Columbia University research centers together with the World Economic Forum (Switzerland) and the Center for Joint Research of the European Commission (Italy).

The quality and effectiveness of the institutes in 2017 was assessed on the basis of six indicators: Voice and Accountability (VA), Political Stability and Absence of Violence (PSAV), Government Effectiveness Index (GEI), Regulatory Quality (RQ), Rule of Law (RL), Control of Corruption (CC), which is an integral part of Worldwide Global Indicator (The Worldwide Governance Indicators, 2018). The estimation of each indicator varies from $-2,5$ (weak) to $+2,5$ (strong) management efficiency. The study used correlation and regression analysis tools using the application statistical software package STATISTICA. In the process of correlation analysis, the pair coefficients of the Pearson correlation are defined, which illustrate the direction and closeness of the linear stochastic coupling between the investigated variables. In the course of regression analysis, linear regression models are constructed that reflect the nature and form of causal relationships between the ethnic diversity of countries and the state of ecology in them. The transitivity of such relationships through the indicators of quality and efficiency of governance is illustrated by linear regression models and bubble diagrams, in which the bubble diameter reflects the integral estimation of the environmental state.

\section{Research results}

Ethnic fractionalization refers to the number, size, socioeconomic distribution and geographical locat- 
Table 1. Criteria for ethnic autonomy, build by the authors based on (Anderson, 2016; Minaeva, Panov, 2017; Ganguly, MacDuff, 2003; Roeder, 2014)

\begin{tabular}{|c|c|}
\hline Ethnic identity of the territory & Preserving autonomy of the ethnic basis \\
\hline $\begin{array}{l}\text { 1) autonomy is provided as a result of an ethno politi- } \\
\text { cal conflict/movement for self-government; } \\
\text { 2) autonomy is provided as a result of the implementa- } \\
\text { tion of the ethno nationalism; } \\
\text { 3) autonomy is provided as a result of the post-imperial } \\
\text { transformation, when the ethnically specific region - } \\
\text { the imperial periphery - remained in the metropolis or } \\
\text { was included in the composition of another state that } \\
\text { arose as a result of the post-imperial transformation }\end{array}$ & $\begin{array}{l}\text { 1) normative consolidation (recognition) of the ethnic nature of the } \\
\text { autonomy (the titular group as a special nationality - distinct na- } \\
\text { tionality); } \\
\text { 2) ethnic identity is expressed in the official attributes of autonomy } \\
\text { (name, symbolism, historical dates, names of political institu- } \\
\text { tions); } \\
\text { 3) official recognition of the language / specific religion of the tit- } \\
\text { ular ethnic group; } \\
\text { 4) special preferences for the titular ethnic group in this region } \\
\text { (guarantees of access to power, language / religious preferences) }\end{array}$ \\
\hline
\end{tabular}

ion of particular cultural groups in a state or in a certain other territory. The specific cultural features of these groups relate to language, skin color, religion, ethnicity, customs and traditions, history, or other specific criterion, individually or in combination (Carment, James, 2004). Often, these features are used for social exclusion and monopolization of power, which runs counter to the principles of democratization and inclusive development.

In practice, for the measurement of ethnic heterogeneity, the index of ethnolinguistic fractionalization (ELF) is most frequently used, which is the probability that two randomly selected members of a society will belong to different groups and are calculated as the Herfindahl index (Bossert et al., 2011; Taylor, Hudson, 1972):

$$
E L F_{j}=1-\sum_{i=1}^{N} s_{i j}^{2} \text {, }
$$

where $s_{i j}$ is the fraction of the group $i(i=1, \ldots, N)$ in the population of the country $j$.

The index varies from 0 (absolutely homogeneous society) to 1 (each member of a society is a separate group). The maximum index of $E L F=0,98$ is in $\mathrm{Pa}-$ pua New Guinea.

However, this index has a rather limited field of application, due both to the difficulty of collecting reliable information on countries (especially those affected by military conflicts), peculiarities of group interaction in providing local public goods, and with distortion of results. So, if in country A there are 7 equal in number of ethnic groups, then $E L F_{A}=0,856$. If in country B there is one group that makes up $35 \%$ of the population and another 13 groups, each of which is $5 \%$, consequently, $E L F_{B}=0,845$ (only slightly lower). However, it is obvious that the impact is differently distributed in these societies: in country B, there is a dominant group that can impose its conditions on others if ethnic heterogeneity prevents them from joining, whereas in country A, such an effect is much harder to realize.

Since ethnic and other cultural minorities have often suffered from other groups in the past, they have vivid memories of their tragedies and fears in the present and future. They cannot trust the state as a benevolent intermediary, since there is always the possibility that it will use private information against them, violating consensus agreements, which usu- ally relate to proportional representation and participation in broad collective decision-making (e.g., Switzerland, the Netherlands, Belgium, European Union) (Lijphart, 1977). However, despite the difference in the position of the majority and the minority of many countries (so-called titular and non-titular ethnic groups), it is often some minorities that are better organized, economically developed and want to manage a majority (e.g., Basques in Spain).

Concerning the optimal number and size of ethnic groups, scholars do not have unanimous opinion. Theoretically, two large groups, commensurate in size, can both balance each other (example of the Wallonians and the Flemish) and create the basis for a multi-year conflict (example of the Israelis and Palestinians). Similarly, a large number of small groups, creating a coalition, can achieve both the maintenance of peace and security in the state, as well as permanent opposition, including armed conflicts. It is precisely in order to avoid the latter that some scholars (Hechter, 2000; Benedikter, 2009; Wolff, 2010) suggest autonomy for certain cultural groups and avoid centralism, since it is decentralization that can restrain militant sentiment (example of Catalans and Basques in Spain, Sicilians in Italy). In this aspect, we are talking about ethnic territorial autonomy, for constructing of which two key criteria have been developed: 1) the ethnic identity of the region in the past; 2) preservation of the autonomy of the ethnic basis at present (table 1).

Table 2 shows the correlation matrix of the pair correlation coefficients between the indicators of ethnic, linguistic, religious fractionalization of the countries and the indices that characterize their ecological situation during the last 19 years. As we can see, between 2006 and 2008, the correlation $(-0,515$ and $-0,523$ ), which is significant (according to Chaddock's table), was found to be inverse between the index of ethnic diversity of countries and the ecological indexes in 2006 and 2008, weak in 2002 and $2005(-0.286$ and - 0,199), in all other years - moderate (from $-0,343$ to $-0,462$ ). Almost all determined correlation coefficients are significant at $0.1 \%$ level, with the exception of the 2000 indicator (significant at $1 \%$ level) and 2005 (significant at 5\% level). Despite a certain difference in the methodology for con- 


\begin{tabular}{|c|c|c|c|c|c|c|c|c|c|c|c|c|c|c|c|}
\hline . & & & & & & & & & & & & & & ০০ & \\
\hline 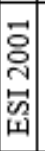 & & & & & & & & & & & & & 을 & 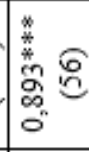 & \\
\hline 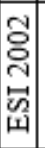 & & & & & & & & & & & & $\stackrel{8}{8.96}$ & 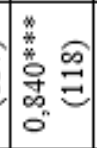 & 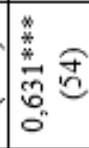 & \\
\hline 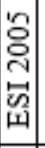 & & & & & & & & & & & 욤 & 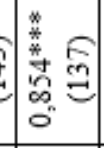 & 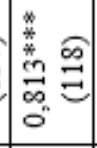 & 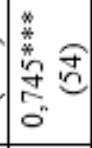 & \\
\hline 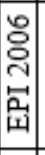 & & & & & & & & & & $\stackrel{\circ}{\circ}$ & 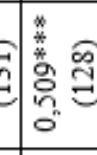 & 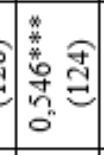 & $\begin{array}{l}* \\
\stackrel{*}{*} \\
\stackrel{*}{*} \\
\underset{\sim}{*} \\
0\end{array}$ & 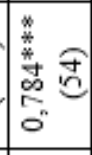 & \\
\hline | & & & & & & & & & 吕告 & 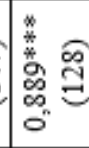 & 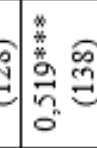 & 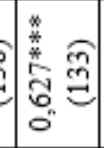 & 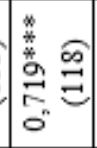 & 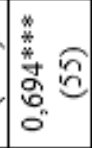 & \\
\hline 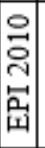 & & & & & & & & 응 & 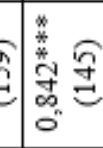 & 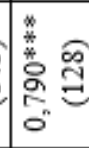 & 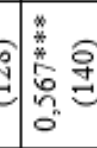 & 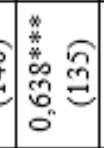 & $\mid \begin{array}{l}* \\
0 \\
0 \\
0 \\
0 \\
0 \\
0\end{array}$ & 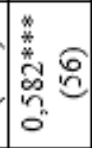 & $\stackrel{2}{\circ}$ \\
\hline 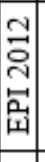 & & & & & & & $\stackrel{\circ}{\circ}$ & 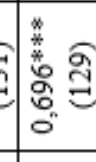 & 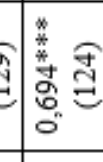 & 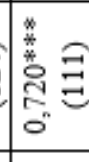 & 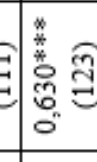 & 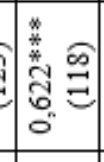 & 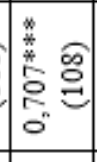 & 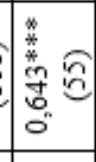 & 旗 \\
\hline 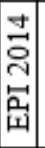 & & & & & & 总胥 & 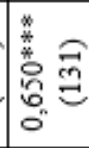 & 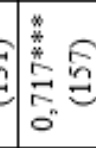 & 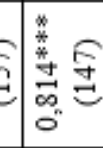 & 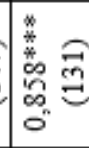 & 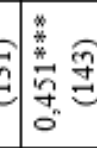 & 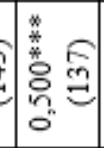 & 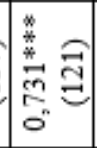 & 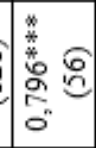 & 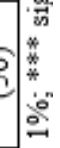 \\
\hline |을 & & & & & $\stackrel{8}{\circ}$ & 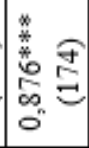 & 蓄。 & 美 & 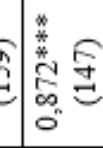 & 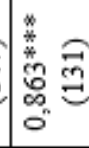 & $\hat{2}$ & 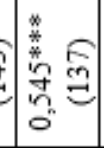 & 类 & $\begin{array}{l}* \\
* \\
* \\
* \\
0 \\
0 \\
0 \\
0\end{array}$ & 雹 \\
\hline 离 & & & & 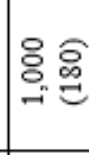 & $\mid \begin{array}{c}* \\
* \\
0 \\
0 \\
0 \\
\infty \\
0 \\
0 \\
0\end{array}$ & $\begin{array}{l}* \\
* \\
* \\
* \\
* \\
\infty \\
\infty \\
0 \\
0 \\
0\end{array}$ & 莫 & 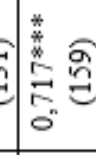 & 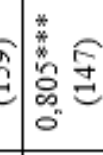 & 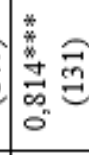 & 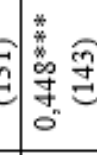 & 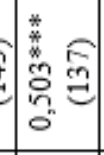 & 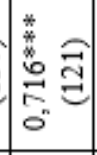 & 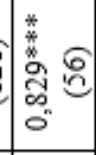 & 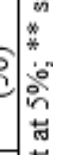 \\
\hline 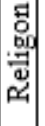 & & & 을 & 용ㄹㅇ & 垥志 & 옹 & 壱 & 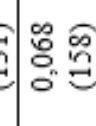 & 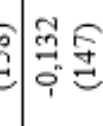 & 总 & to & {$\left[\begin{array}{ll}\vec{n} & 6 \\
0 & 0 \\
0 & =\end{array}\right.$} & 응 & $\overrightarrow{2}$ & 蹇 \\
\hline 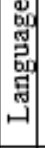 & & 응응 & 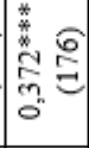 & 总 2 & 管 & $\frac{c}{2}=$ & 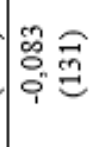 & $\underline{a}$ & 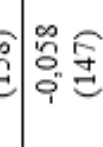 & {$\left[\begin{array}{l}n \\
0 \\
0 \\
0\end{array}\right.$} & 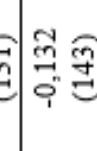 & 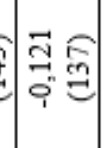 & 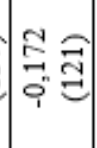 & 高 & 施 \\
\hline 趗 & 8. & $\begin{array}{ll} & 0 \\
0 & 0 \\
0 & 0\end{array}$ & 每 & 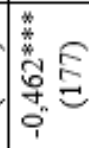 & 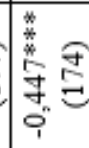 & 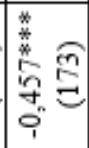 & 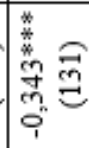 & 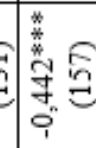 & 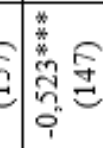 & 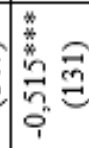 & $\hat{\mathrm{g}}$ & 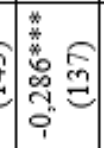 & 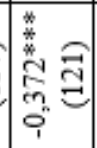 & $\begin{array}{l}* \\
8 \\
0 \\
0 \\
0 \\
0 \\
1\end{array}$ & 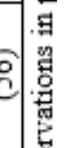 \\
\hline & 㮍 & $\begin{array}{l}\text { 品 } \\
\text { 范 } \\
\text { 嵒 } \\
\text { 舀 }\end{array}$ & 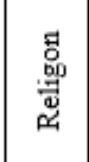 & 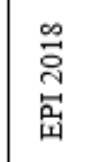 & 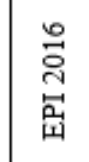 & 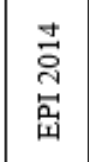 & $\begin{array}{l}\text { בี } \\
\text { 岀 }\end{array}$ & $\begin{array}{l}\text { 옥 } \\
\text { 岕 }\end{array}$ & 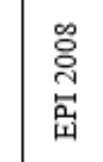 & 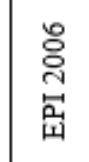 & 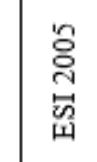 & 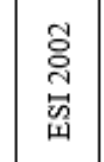 & 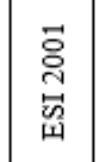 & 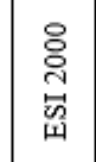 & 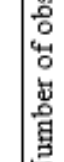 \\
\hline
\end{tabular}

Table 2. Correlations of Fractionalization measures and Environment indexes, build by the authors 
Table 3. Ethnicity as a Determinant of Ecological Indicators (Linear Regression Analysis), build by the authors

\begin{tabular}{|c|c|c|c|c|c|}
\hline \multirow{2}{*}{$\begin{array}{c}\text { Dependent } \\
\text { variable }\end{array}$} & \multirow{2}{*}{$\begin{array}{c}\text { Intercept } \\
\mathrm{b}_{0}\end{array}$} & \multirow{2}{*}{$\begin{array}{c}\text { Ethnic } \\
\mathrm{b}_{1}\end{array}$} & \multirow{2}{*}{$\mathrm{R}^{2}$} & \multirow{2}{*}{$\mathrm{F}$} & \multirow{2}{*}{$\begin{array}{c}\text { Number of } \\
\text { observations }\end{array}$} \\
\hline & & & & & \\
\hline EPI 2018 & $\begin{array}{l}66,785 \\
(0,000) \\
\end{array}$ & $\begin{array}{r}-23,344 \\
(0,000) \\
\end{array}$ & 0,213 & 47,35 & 177 \\
\hline EPI 2016 & $\begin{array}{l}79,130 \\
(0,000) \\
\end{array}$ & $\begin{array}{l}-25,308 \\
(0,000) \\
\end{array}$ & 0,200 & 42,89 & 174 \\
\hline EPI 2014 & $\begin{array}{l}64,022 \\
(0,000)\end{array}$ & $\begin{array}{l}-29,240 \\
(0,000)\end{array}$ & 0,209 & 45,16 & 173 \\
\hline EPI 2012 & $\begin{array}{l}58,968 \\
(0,000) \\
\end{array}$ & $\begin{array}{r}-13,628 \\
(0,000) \\
\end{array}$ & 0,117 & 17,16 & 131 \\
\hline EPI 2010 & $\begin{array}{l}68,549 \\
(0,000)\end{array}$ & $\begin{array}{l}-22,116 \\
(0,000)\end{array}$ & 0,195 & 37,66 & 157 \\
\hline EPI 2008 & $\begin{array}{l}83,889 \\
(0,000) \\
\end{array}$ & $\begin{array}{l}-26,287 \\
(0,000) \\
\end{array}$ & 0,273 & 54,51 & 147 \\
\hline EPI 2006 & $\begin{array}{l}77,101 \\
(0,000)\end{array}$ & $\begin{array}{l}-27,472 \\
(0,000) \\
\end{array}$ & 0,265 & 46,43 & 131 \\
\hline ESI 2005 & $\begin{array}{l}53,153 \\
(0,000) \\
\end{array}$ & $\begin{array}{l}-6,503 \\
(0,017) \\
\end{array}$ & 0,039 & 5,79 & 143 \\
\hline ESI 2002 & $\begin{array}{l}54,434 \\
(0,000)\end{array}$ & $\begin{array}{r}-10,130 \\
(0,001) \\
\end{array}$ & 0,082 & 12,02 & 137 \\
\hline ESI 2001 & $\begin{array}{l}56,866 \\
(0,000) \\
\end{array}$ & $\begin{array}{l}-17,256 \\
(0,000) \\
\end{array}$ & 0,138 & 19,10 & 121 \\
\hline ESI 2000 & $\begin{array}{l}65,554 \\
(0,000) \\
\end{array}$ & $\begin{array}{r}-15,850 \\
(0,003) \\
\end{array}$ & 0,157 & 10,03 & 56 \\
\hline
\end{tabular}

$\mathrm{p}$ - statistic in parentheses, critical $\mathrm{F}_{0,05}$-value $(1,54)=4,02, \mathrm{~F}_{0,01}$-value $(1,141)=3,91$

structing the ESI and EPI indices, as well as the continuous improvement of the structure and algorithm for calculating the latter, and also taking into account the values of the calculated Pearson coefficients, it is safe to assert that there is a reliable linear relationship between the ethnic fractionalization of the country and the ecological situation in it. The form and nature of this connection are illustrated by the data in table 3, that presents the results of the regression analysis of these indicators. All constructed regression models are statistically significant with the reliable values of the free member and the regression coefficient. However, the determination coefficients for models are low, which indicates that only a certain part $(3,9-27,3 \%$ in different years) of the variability of the environmental index in the countries was due to their ethnic diversity. This is quite a logical explanation, since the indicator of ethnic fractionalization cannot be the only determinant of the ecological situation in the country.

Moreover, as already noted in the part of the hypothesis's formulation, the connection between these indicators is obviously an inverse, and most likely, has a transitive nature. Therefore, an important application task is to find out the structure and nature of the action of the transmission buffer mechanism between the phenomena of ethnic diversity and ecological situation in the country. It should be noted that the correlation analysis did not establish a reliable link between the indices of language and religious diversity in the country and the indices that characterize the environmental state in it. As we see from table 2, the absolute values of the correlation coefficients between these indices are insignificant $(0,003$ $0,195)$, and their signs vary in different years.
In order to test the hypothesis about the role of state institutions as components of the above-mentioned transmission buffer mechanism and their quality as a necessary condition for its effectiveness, a correlation-regression analysis was conducted to establish the causal link between the indicators of ethnic fractionalization and the ecological situation, as well as the transitive dependence between them because of the institutional characteristics of the states.

Table 4 shows the correlation coefficients between the indicator of ethnic diversity in the country and indicators of the quality of governance in it. With all indicators of the quality of state institutions, the correlation is moderate and has a negative sign $(\mathrm{r}=$ $-0,385 \div-0,467)$. The statistical significance of the calculated pair coefficients of correlation is high (at $0.1 \%$ level). The constructed linear regression models (table 5), in which the variables are an indicator of ethnic diversity, but dependent - one of the indicators of the quality of state institutions (GEI, VA, PSAV, RQ, RL, CC), proved to be adequate for all criteria with statistically significant all coefficients. Thus, the calculated Fisher F-criterion for all models ranged from 3,51 to 48,8 and was significantly higher than its critical (tabular) value $\mathrm{F}_{0,01}(1,175)=$ 6,79 .

Correlation matrix (table 6) illustrates the direction and the power of interdependence between the elements of the other part of the transmission mechanism - from quality and efficiency criteria of state institutions to the ecological quality. As shown in the table 6 , there is a closer relationship that is identified by the Chaddock scale as direct significant (for PSAV, VA and CC r $=0.577 \div 0.693$ ) and strong (for $\mathrm{RL}, \mathrm{RQ}$ and GEI $r=0,792 \div 0,787)$. The results of 
Table 4. Correlations of Ethnic Fractionalization and aggregate indicators of six broad dimensions of governance, build by the authors

\begin{tabular}{|c|c|c|c|c|c|c|c|}
\hline & Ethnic & GEI & VA & PSAV & RQ & RL & CC \\
\hline Ethnic & 1,000 & & & & & & \\
\hline GEI & $-0,436 * * *$ & 1,000 & & & & & \\
\hline VA & $-0,385 * * *$ & $0,691 * * *$ & 1,000 & & & & \\
\hline PSAV & $-0,411^{* * *}$ & $0,689 * * *$ & $0,643 * * *$ & 1,000 & & & \\
\hline RQ & $-0,423 * * *$ & $0,934 * * *$ & $0,742 * * *$ & $0,640 * * *$ & 1,000 & & \\
\hline RL & $-0,467 * * *$ & $0,938^{* * *}$ & $0,763 * * *$ & $0,734 * * *$ & $0,925 * * *$ & 1,000 & \\
\hline CC & $-0,446 * * *$ & $0,903 * * *$ & $0,758^{* * *}$ & $0,740 * * *$ & $0,860 * * *$ & $0,940 * * *$ & 1,000 \\
\hline
\end{tabular}

Number of observations $-177-180, *$ significant at $5 \%$; ** significant at $1 \%$; *** significant at $0,1 \%$

Table 5. Ethnicity as a Determinant of Indicators of Governance Quality (Linear Regression Analysis), build by the authors

\begin{tabular}{|c|c|c|c|c|c|}
\hline $\begin{array}{c}\text { Dependent } \\
\text { variable }\end{array}$ & Intercept & Ethnic & \multirow{2}{*}{$\mathrm{R}^{2}$} & $\mathrm{~F}$ & $\begin{array}{c}\text { Number of } \\
\text { observations }\end{array}$ \\
\cline { 2 - 3 } GEI & $\begin{array}{c}0,691 \\
(0,000)\end{array}$ & $\begin{array}{c}-1,605 \\
(0,000)\end{array}$ & 0,190 & 41,08 & 177 \\
\hline VA & $\begin{array}{c}0,614 \\
(0,000)\end{array}$ & $\begin{array}{c}-1,458 \\
(0,000)\end{array}$ & 0,148 & 30,51 & 177 \\
\hline PSAV & $\begin{array}{c}0,581 \\
(0,000)\end{array}$ & $\begin{array}{c}-1,476 \\
(0,000)\end{array}$ & 0,169 & 35,55 & 177 \\
\hline RQ & $\begin{array}{c}0,681 \\
(0,000)\end{array}$ & $\begin{array}{c}-1,576 \\
(0,000)\end{array}$ & 0,179 & 38,20 & 177 \\
\hline RL & $\begin{array}{c}0,724 \\
(0,000)\end{array}$ & $\begin{array}{c}-1,731 \\
(0,000)\end{array}$ & 0,218 & 48,80 & 177 \\
\hline CC & $\begin{array}{c}0,700 \\
(0,000)\end{array}$ & $\begin{array}{c}-1,700 \\
(0,000)\end{array}$ & 0,199 & 43,40 & 177 \\
\hline
\end{tabular}

$\mathrm{p}$ - statistic in parentheses, critical $\mathrm{F}_{0,05}$-value $(1,175)=3,90, \mathrm{~F}_{0,01}$-value $(1,175)=6,79$

Table 6. Correlations of Ecological indicator and aggregate indicators of six broad dimensions of governance, build by the authors

\begin{tabular}{|c|c|c|c|c|c|c|c|}
\hline & EPI 2018 & GEI & VA & PSAV & RQ & RL & CC \\
\hline EPI 2018 & 1,000 & & & & & & \\
\hline GEI & $0,787 * * *$ & 1,000 & & & & & \\
\hline VA & $0,601 * * *$ & $0,691 * * *$ & 1,000 & & & & \\
\hline PSAV & $0,577 * * *$ & $0,689 * * *$ & $0,643 * * *$ & 1,000 & & & \\
\hline RQ & $0,738 * * *$ & $0,934 * * *$ & $0,742 * * *$ & $0,640 * * *$ & 1,000 & & \\
\hline RL & $0,729 * * *$ & $0,938 * * *$ & $0,763 * * *$ & $0,734 * * *$ & $0,925 * * *$ & 1,000 & \\
\hline CC & $0,693 * * *$ & $0,903 * * *$ & $0,758^{* * *}$ & $0,740 * * *$ & $0,860 * * *$ & $0,940 * * *$ & 1,000 \\
\hline
\end{tabular}

Number of observations $-180, *$ significant at $5 \%$; ** significant at $1 \%$; *** significant at $0,1 \%$

Table 7. Indicators of Governance Quality as a Determinants of Environment Performance - EPI 2018 (Linear Regression Analysis), build by the authors

\begin{tabular}{|c|c|c|c|c|c|}
\hline $\begin{array}{c}\text { Independent } \\
\text { variable }\end{array}$ & $\mathrm{b}_{0}$ & $\mathrm{~b}_{1}$ & $\mathrm{R}^{2}$ & $\mathrm{~F}$ & $\begin{array}{c}\text { Number of } \\
\text { observations }\end{array}$ \\
\hline GEI & $\begin{array}{c}56,73 \\
(0,000)\end{array}$ & $\begin{array}{c}10,76 \\
(0,000)\end{array}$ & 0,618 & 288,97 & 180 \\
\hline VA & $\begin{array}{c}56,64 \\
(0,000)\end{array}$ & $\begin{array}{c}8,02 \\
(0,000)\end{array}$ & 0,361 & 100,63 & 180 \\
\hline PSAV & $\begin{array}{c}56,95 \\
(0,000) \\
\end{array}$ & $\begin{array}{c}8,13 \\
(0,000) \\
\end{array}$ & 0,333 & 88,86 & 180 \\
\hline RQ & $\begin{array}{c}56,66 \\
(0,000)\end{array}$ & $\begin{array}{c}10,00 \\
(0,000)\end{array}$ & 0,545 & 213,42 & 180 \\
\hline RL & $\begin{array}{c}56,92 \\
(0,000)\end{array}$ & $\begin{array}{c}9,90 \\
(0,000)\end{array}$ & 0,532 & 202,23 & 180 \\
\hline $\mathrm{CC}$ & $\begin{array}{c}56,92 \\
(0,000)\end{array}$ & $\begin{array}{c}9,19 \\
(0,000)\end{array}$ & 0,481 & 164,86 & 180 \\
\hline
\end{tabular}

$\mathrm{p}$ - statistic in parentheses, critical $\mathrm{F}_{0,05}$-value $(1,178)=3,89, \mathrm{~F}_{0,01}$-value $(1,178)=6,78$

the regression analysis, in which as the dependent variable the indicator of the ecological situation in the countries for 2018 was chosen as an independent variable, and the quality indicators of state institutions in 2017 (table 7) statistically confirm the exist- ence of causal relationships between the above pairs of variables. So, the determination coefficient $\left(\mathrm{R}^{2}\right)$ for all constructed models is within the limits of $0,333 \div 0,618$, Fisher criterion $(\mathrm{F})$ is $88,86 \div 288,97$ at $\mathrm{F}_{0,01}(1,178)=6,78$. 

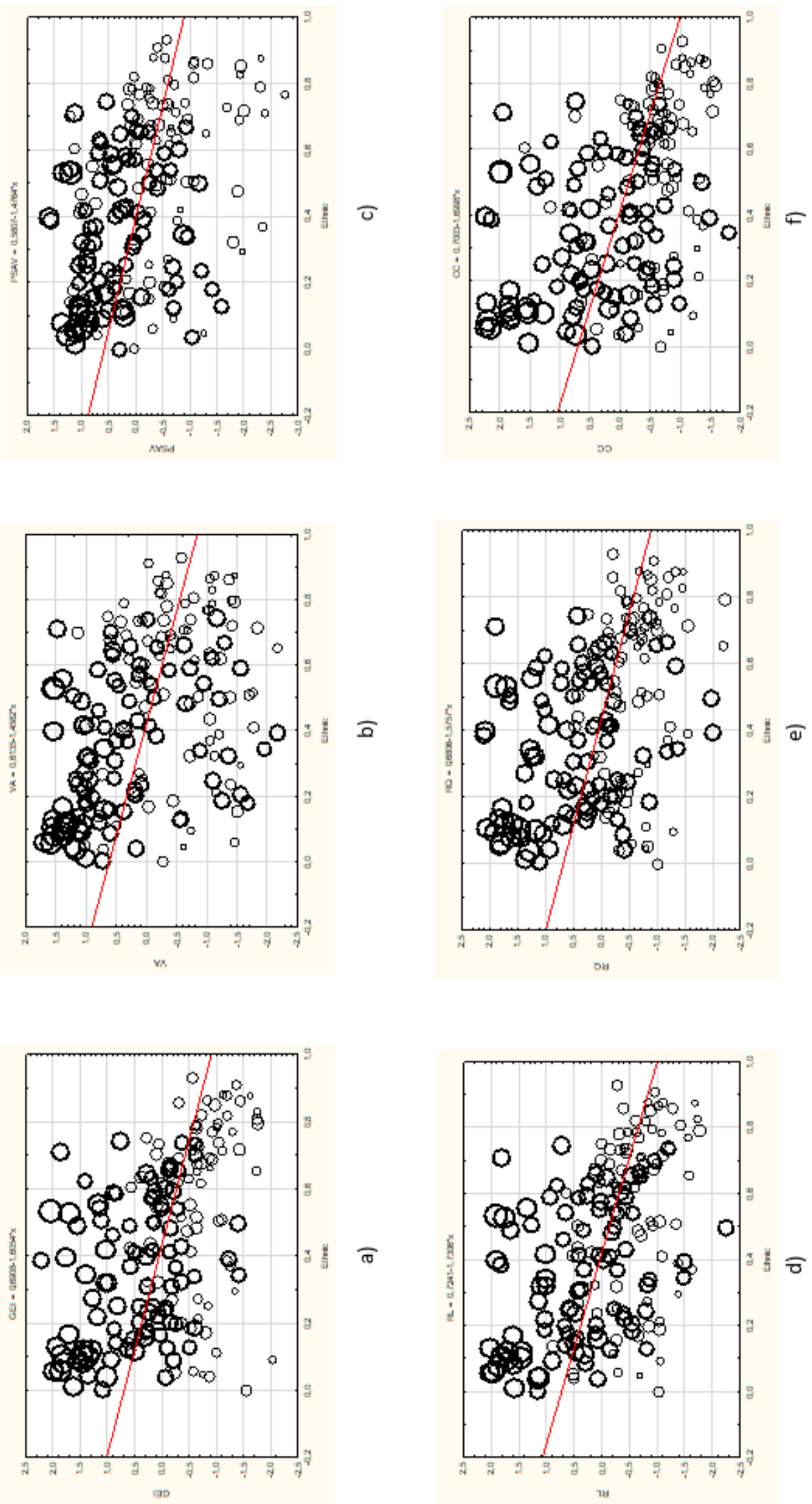

Figure 1. Bubble 2D Scatterplot ( $\mathrm{X}$ axis - Measure of Ethnic Fractalization, $\mathrm{Y}$ axis - governance indicator a) GEI; b) VA; c) PSAV; d) RL; e) RQ; f) CC; Size of bubble - EPI, build by the authors based on (Environment Performance Index, 2018; The Worldwide Governance Indicators, 2018) 
Table 8. Basic parameters of the multiple linear regression model: regressors - Index of ethnic fractionalization and Government effectiveness index, regressant - Environmental performance index, build by the authors

\begin{tabular}{|c|c|c|c|c|c|c|}
\hline \multicolumn{7}{|c|}{ Regression summary for dependent variable: EPI 2014-2018 } \\
& $\mathrm{R}=0,844$ & $\mathrm{R}^{2}=0,712$ & Adjusted $\mathrm{R}^{2}=0,709$ & $\mathrm{~F}(2,174)=215,57$ & $\mathrm{p}<0,0000$ & $\mathrm{p}$-value \\
\hline & $\mathrm{b}^{*}$ & Std.Err. - of $\mathrm{b}^{*}$ & $\mathrm{~b}$ & Std.Err. - of $\mathrm{b}$ & $\mathrm{t}(14)$ & 0,000 \\
\hline Inercept & & & 61,900 & 1,221 & 50,685 & 0,003 \\
\hline Ethnic & $-0,135$ & 0,045 & $-7,335$ & 2,464 & $-2,978$ & 0,000 \\
\hline
\end{tabular}

Table 9. Partial und semipartial correlation between dependent and independent variables in the multiple regression model, based on table 8

\begin{tabular}{|c|c|c|c|c|c|c|c|}
\hline & \multicolumn{7}{|c|}{ Dependent variable: EPI 2014-2018 } \\
\cline { 2 - 9 } & $\mathrm{b} *$ in & Partial - Cor. & $\begin{array}{c}\text { Semipart - } \\
\text { Cor. }\end{array}$ & Tolerance & R-square & $\mathrm{t}(174)$ & p-value \\
\hline Ethnic & $-0,135$ & $-0,220$ & $-0,121$ & 0,807 & 0,193 & $-2,98$ & 0,0033 \\
\hline GEI 2014-2017 & 0,776 & 0,793 & 0,697 & 0,807 & 0,193 & 17,16 & 0,0000 \\
\hline
\end{tabular}

Table 10. Ethnic Fractionalization, Governance Indicators and Environment Performance Index of OECD members, build by the authors, *based on (GDP per capita, 2017)

\begin{tabular}{|c|c|c|c|c|c|c|c|c|c|}
\hline Country & $\begin{array}{l}\text { GDP per } \\
\text { capita* }\end{array}$ & Ethnic & GEI & VA & PSAV & RQ & RL & $\mathrm{CC}$ & EPI 2018 \\
\hline Australia & 53800 & 0,0929 & 1,54 & 1,38 & 0,90 & 1,93 & 1,68 & 1,80 & 74,12 \\
\hline Austria & 47291 & 0,1068 & 1,46 & 1,34 & 1,04 & 1,44 & 1,81 & 1,53 & 78,97 \\
\hline Belgium & 43324 & 0,5554 & 1,18 & 1,38 & 0,42 & 1,24 & 1,34 & 1,50 & 77,38 \\
\hline Canada & 45032 & 0,7124 & 1,85 & 1,48 & 1,11 & 1,89 & 1,80 & 1,92 & 72,18 \\
\hline Chile & 15346 & 0,1861 & 0,85 & 1,00 & 0,38 & 1,34 & 1,01 & 1,04 & 57,49 \\
\hline Czech Rep. & 20368 & 0,3222 & 1,02 & 0,97 & 1,02 & 1,23 & 1,12 & 0,57 & 67,68 \\
\hline Denmark & 56308 & 0,0819 & 1,80 & 1,52 & 0,87 & 1,62 & 1,86 & 2,19 & 81,60 \\
\hline Estonia & 19705 & 0,5062 & 1,12 & 1,21 & 0,66 & 1,64 & 1,28 & 1,24 & 64,31 \\
\hline Finland & 45703 & 0,1315 & 1,94 & 1,55 & 1,07 & 1,82 & 2,03 & 2,22 & 78,64 \\
\hline France & 38477 & 0,1032 & 1,35 & 1,15 & 0,21 & 1,16 & 1,44 & 1,26 & 83,95 \\
\hline Germany & 44470 & 0,1682 & 1,72 & 1,39 & 0,58 & 1,78 & 1,61 & 1,84 & 78,37 \\
\hline Greece & 18613 & 0,1576 & 0,31 & 0,71 & $-0,13$ & 0,24 & 0,08 & $-0,14$ & 73,60 \\
\hline Hungary & 14225 & 0,1522 & 0,51 & 0,37 & 0,81 & 0,65 & 0,53 & 0,09 & 65,01 \\
\hline Iceland & 70057 & 0,0798 & 1,45 & 1,38 & 1,37 & 1,43 & 1,61 & 1,84 & 78,57 \\
\hline Ireland & 69331 & 0,1206 & 1,29 & 1,29 & 1,02 & 1,59 & 1,43 & 1,55 & 78,77 \\
\hline Israel & 40270 & 0,3436 & 1,39 & 0,70 & $-0,88$ & 1,27 & 1,02 & 0,83 & 75,01 \\
\hline Italy & 31953 & 0,1145 & 0,50 & 1,05 & 0,24 & 0,70 & 0,32 & 0,19 & 76,96 \\
\hline Japan & 38428 & 0,0119 & 1,62 & 1,01 & 1,12 & 1,37 & 1,57 & 1,52 & 74,69 \\
\hline Luxembourg & 104103 & 0,5302 & 1,68 & 1,52 & 1,34 & 1,69 & 1,74 & 1,99 & 79,20 \\
\hline Mexico & 8910 & 0,5418 & $-0,03$ & $-0,08$ & $-0,65$ & 0,20 & $-0,57$ & $-0,93$ & 59,69 \\
\hline Netherland & 48223 & 0,1054 & 1,85 & 1,57 & 0,92 & 2,05 & 1,83 & 1,87 & 75,46 \\
\hline New Zealand & 42941 & 0,3969 & 1,77 & 1,56 & 1,59 & 2,09 & 1,92 & 2,24 & 75,96 \\
\hline Norway & 75565 & 0,0586 & 1,98 & 1,69 & 1,15 & 1,81 & 2,02 & 2,24 & 77,49 \\
\hline Poland & 13863 & 0,1183 & 0,63 & 0,78 & 0,52 & 0,88 & 0,47 & 0,73 & 64,11 \\
\hline Portugal & 21136 & 0,0468 & 1,33 & 1,21 & 1,08 & 0,91 & 1,13 & 0,87 & 71,91 \\
\hline Slovak Rep. & 17605 & 0,2539 & 0,81 & 0,94 & 0,88 & 0,82 & 0,57 & 0,22 & 70,60 \\
\hline Slovenia & 23597 & 0,2216 & 1,17 & 1,00 & 0,89 & 0,58 & 1,02 & 0,81 & 67,57 \\
\hline Spain & 28157 & 0,4165 & 1,03 & 1,03 & 0,27 & 0,94 & 1,01 & 0,49 & 78,39 \\
\hline South Korea & 29742 & 0,0020 & 1,08 & 0,74 & 0,29 & 1,11 & 1,16 & 0,48 & 62,30 \\
\hline Sweden & 53442 & 0,0600 & 1,84 & 1,58 & 0,98 & 1,80 & 1,94 & 2,14 & 80,51 \\
\hline Switzerland & 80189 & 0,5314 & 2,06 & 1,56 & 1,21 & 1,88 & 1,93 & 1,99 & 87,42 \\
\hline Turkey & 10546 & 0,3200 & 0,07 & $-0,71$ & $-1,80$ & 0,04 & $-0,25$ & $-0,19$ & 52,96 \\
\hline UK & 39720 & 0,1211 & 1,41 & 1,33 & 0,26 & 1,71 & 1,68 & 1,84 & 79,89 \\
\hline USA & 59532 & 0,4901 & 1,55 & 1,05 & 0,30 & 1,63 & 1,64 & 1,38 & 71,19 \\
\hline
\end{tabular}

Thus, the results of the statistical analyzes confirmed by the first two working hypotheses of the study. The visual effect of the individual elements of the transmission buffer mechanism of the determination of the ecological state of the country illustrates the fig. 1. As we see, in the left upper quadrant (low ethnic fractionalization and high quality of state institutions), in all scatter diagrams, countries with predominantly high environmental quality dominate and vice versa. That is, in countries that are simultaneously characterized by high ethnic fractionalization and low quality and efficiency of state institu- 
Table 11. Correlations of Ethnic Fractionalization, aggregate indicators of six broad dimensions of governance, Environmental Performance Index and GDP per capita for OECD members, build by the authors

\begin{tabular}{|c|c|c|c|c|c|c|c|c|c|}
\hline & Ethnic & GEI & VA & PSAV & RQ & RL & CC & EPI 2018 & $\begin{array}{c}\text { GDP per } \\
\text { capita }\end{array}$ \\
\hline Ethnic & 1,000 & & & & & & & & \\
\hline GEI & $-0,047$ & 1,000 & & & & & & & \\
\hline VA & $-0,091$ & $0,856^{* * *}$ & 1,000 & & & & & & \\
\hline PSAV & $-0,133$ & $0,662^{* * *}$ & $0,806^{* * *}$ & 1,000 & & & & & \\
\hline RQ & 0,027 & $0,904^{* * *}$ & $0,843^{* * *}$ & $0,640^{* * *}$ & 1,000 & & & & \\
\hline RL & $-0,093$ & $0,968^{* * *}$ & $0,882^{* * *}$ & $0,705^{* * *}$ & $0,927 * * *$ & 1,000 & & & \\
\hline CC & $-0,079$ & $0,937^{* * *}$ & $0,864^{* * *}$ & $0,658^{* * *}$ & $0,923^{* * *}$ & $0,957 * * *$ & 1,000 & & \\
\hline EPI 2018 & $-0,108$ & $0,698^{* * *}$ & $0,757^{* * *}$ & $0,496^{* *}$ & $0,572^{* * *}$ & $0,676^{* * *}$ & $0,661 * * *$ & 1,000 & \\
\hline $\begin{array}{c}\text { GDP } \\
\text { per capita }\end{array}$ & 0,068 & $0,743^{* * *}$ & $0,669^{* * *}$ & $0,500^{* *}$ & $0,688^{* * *}$ & $0,728^{* * *}$ & $0,754 * * *$ & $0,706^{* * *}$ & 1,000 \\
\hline
\end{tabular}

Number of observations $-34, *$ significant at $5 \% ; * *$ significant at $1 \% ; * * *$ significant at $0,1 \%$

tions, the latter are not able to fully perform the buffer role, that is, to neutralize the negative impact of different models of ethnic interests on decision making and the introduction of appropriate environmental policies. This means that this mechanism in such countries performs mainly a transmission (transfer) function.

To assess the mutual influence of ethnic fractionalization and the effectiveness of governance in the country on the ecological state, a two-factor regression analysis was carried out in which the average value of the EPI index for 2014, 2016 and 2018 was used as a regressant, and as regressors, the index of ethnic fractionalization and the average index of GEI for 2014, 2016 and 2017. As can be seen from the table 8 , the resulting model is significant for all criteria. Fisher F-criterion is 215,57 per $\quad F_{0,01}(2,174)$ $=4,73$, and the determination coefficient is quite high $\left(R^{2}=0,712\right)$. This indicates that $71,2 \%$ of the variation of the dependent variable is due to the variability of the independent variables. Regression coefficients and free membership in the constructed model are highly significant at $1 \%$ level.

Analytically the model has the form:

$Y=61,9-7,34 x_{1}+11,44 x_{2}$,

where $y$ is EPI 2014-2018, $x_{1}$ - Index of ethnic fractionalization, $x_{2}$ is GEI 2014-2017.

The value of the standardized regression coefficients $b^{*}$ indicates that the predictor of government effectiveness affects the environmental state in the country more than its ethnic diversity $(0,776$ vs $-0,135)$. However, as the comparison of partial and semi-partial coefficients of correlation between dependent and independent variables shows (table 9), none of the predictors (first of all GEI) does not have an independent part in explaining the variability of the values of the dependent variable. This suggests that, with a high probability, the influence (direct and indirect) of these predictors on ecology should be analyzed together.

Hypothetically, in countries that are characterized by a set of signs as welfare states, strong and qualitatively functioning institutions should act as buffer elements of such a mechanism and neutralize the neg- ative impact of inter-ethnic conflicts on the elaboration and implementation of political decisions, including environmental policy.

To test this hypothesis, a correlation analysis of ethnic diversity indices, institutional quality and efficiency and ecological situation in the OECD countries is conducted, the vast majority of which can be identified as welfare states (table 10). Among the members of this group are countries with high levels of ethnic diversity (e.g. Canada, Belgium, Mexico, Switzerland, Luxembourg) and almost mono-ethnic (Japan, South Korea, Portugal, Norway, Sweden, Iceland). At the same time, almost all OECD countries are characterized by high quality and efficiency in governance and the environment.

According to the correlation matrix data (table 11), the correlation coefficients between the ethnic fractionalization of the OECD countries and other indicators are low and statistically insignificant. In the welfare states, the transmission buffer mechanism, through the perfection of state institutions, eliminates the danger of interethnic conflicts, harmonizes their economic, social, cultural and environmental interests, and thus contributes to the development of a balanced and effective environmental policy.

\section{Conclusions and perspectives for further re- search}

Summarizing the problem of relationship between ethnic fractionalization and the ecological situation in the countries, the following conclusions can be drawn:

1. Ethnic fractionalization is considered to be a significant obstacle to inclusive growth and the establishment of quality governance institutions. The presence of inter-ethnic tensions often becomes a prerequisite for the policy of restricting competition to other groups. However, because of the high level of quality of governance institutions between ethnic fractionalization and inclusive development, conflicts are eliminated.

2. Environmental goods may be the subject of a redistributive policy in heterogeneous societies. 
As a rule, this is not so much direct expropriation of the welfare of individual groups, as the inability to negotiate goods with significant external effects, the benefits of which are consumed by all.

3. Empirically confirmed the hypothesis of an inverse relationship between the degree of heterogeneous society and the environmental quality. It was found that the quality of governance could weaken the inverse relationship between ethnic fractionalization and the ecological situation in the country. Typically, in the welfare states, the neutralization factor of ethnic fractionalization by the quality of governance institutions can be traced. This means that there is an institutional transmission buffer mechanism in the relationship between the structure of society and the offer of environmental goods.

\section{References}

1. ACEMOGLU D., ROBINSON J.A., 2006, Economic Origins of Dictatorship and Democracy, Cambridge University Press, New York.

2. AHLQUIST J.S., WIBBELS E., 2012, Riding the Wave: World Trade and Factor-Based Models of Democratization, in: American Journal of Political Science, 56(2), p. 447-464.

3. AKHREMENKO A., PETROV A., PHILIPPOV I., 2018, Democratic survival and stability: from Lipset hypothesis to economic productivity, in: Politia, 3(90), p. 87-112. DOI: 10.30570/2078-5089-2018-90-3-87-112.

4. ALESINA A., DEVLEESCHAUWER A., EASTERLY W., KURLAT S., WACZIARG R., 2003, Fractionalization, in: Journal of Economic Growth, 8(2), p. 155-194.

5. ALESINA A., GENNAIOLI C., LOVO S., 2019, Public Goods and Ethnic Diversity: Evidence from Deforestation in Indonesia, in: Economica, 86(341), p. 32-66. DOI: 10.3386/w20504.67.

6. ALESINA A., FERRARA E., 2005, Ethnic Diversity and Economic Performance, in: Journal of Economic Literature, 43, p. 762-800.

7. ANDERSON L., 2016, Ethnofederalism and the management of ethnic conflict: Assessing the alternatives, in: Publius: The Journal of Federalism, 46(1), p. 1-24.

8. BENEDIKTER T., 2009, Solving ethnic conflict through self-government: a short guide to autonomy in South Asia and Europe, Europe Academia, Bolzano.

9. BERNHARD M., NORDSTROM T., REENOCK CH., 2001, Economic Performance, Institutional Intermediation, and Democratic Survival, in: The Journal of Politics, 63(3), p. 775-803.

10. BOIX C., STOKES S., 2003, Endogenous Democratization, in: World Politics, 55, p. 517-549.

11. BOSSERT W., D'AMBROSIO C., LA FERRARA, E., 2011, A Generalized Index of Fractionalization, Economica, 78, p. 723-750.

12. BURGESS R., HANSEN M., OLKEN B., POTAPOV P., SIEBER S., 2011, The political economy of deforestation in the tropics, in: Working Paper Series, National Bureau of Economic Research, 17417.
13. CANNING D., FAY M., 1993, The Effects of Transportation Networks on Economic Growth, Columbia University Working Paper.

14. CARMRNT D., JAMES P., 2004, Third-Party States in Ethnic Conflict: Identifying the Domestic Determinants of Intervention, in: Ethnic Conflict and International Politics: Explaining Diffusion and Escalation, eds. Lobell, S.E., Mauceri, Ph., Palgrave, New York, p. 11-34.

15. COLliER P., HOEFFLER A., 2004, Conflict, in: Global Crises, Global Solutions, ed. Lomborg, B., Cambridge University Press, New York, p. 129-156.

16. DAVIES J., 1962, Toward a Theory of Revolution, in: American Sociological Review, 27(1), p. 5-19.

17. DAVIS G., MCADAM D., SCOTT W.R., ZALD M.N., 2005, Social Movements and Organizations, Cambridge University Press, New York.

18. DEUTSCH K.W., 1966, Nationalism and Social Communication: an Inquiry into the Foundations of Nationality, MIT Press, Cambridge.

19. DLUHOPOLSKYI O., 2012, Institutional measurement of social capital development: theoretical, methodological and practice aspects, in: Economy of Ukraine, 12, p. 17-29.

20. DLUHOPOLSKYI O., KOZIUK, V., IVASHUK Y., KLAPKIV Y., 2019, Environmental Welfare: Quality of Policy vs. Society's Values, in: Problemy Ekorozwoju / Problems of Sustainable Development, 4(1), p. 19-28.

21. DLUHOPOLSKYI O., ZATONATSKA T., LVOVA I., KLAPKIV Y., 2019, Regulations for returning labour migrants to Ukraine: international background and national limitations, in: Comparative Economic Research. Central and Eastern Europe, 22(3), p. 4564.

22. DUNNING TH., 2008, Crude Democracy: Natural Resource Wealth and Political Regimes, Cambridge University Press, Cambridge.

23. EASTERLY W., LEVINE R., 1997, Africa's Growth Tragedy: Policies and Ethnic Divisions, in: Quarterly Journal of Economics, 111(4), p. 1203-1250.

24. ENVIRONMENTAL PERFORMANCE INDEX (EPI), http://sedac.ciesin.columbia.edu/data/collectio n/epi/sets/browse.

25. ENVIRONMENTAL SUSTAINABILITY INDEX (ESI), http://sedac.ciesin.columbia.edu/data/collecti on/esi/sets/browse.

26. ESTEBAN J.-M., RAY D., 1994, On the measurement of polarization, in: Econometrica, 62, p. 819851.

27. FEARON J.D., 2003,. Ethnic and cultural diversity by country, in: Journal of Economic Growth, 8, p. 195-222.

28. FISH M., KROENING M., 2006, Diversity, Conflict and Democracy: Some Evidence from Eurasia and East Europe, in: Democratization, 13(5), p. 828842.

29. GANGULY R., MACDUFF I., 2003, Ethnic conflict and secessionism in South and Southeast Asia: Causes, dynamics, solutions, Sage Publications, Thousand Oaks, California.

30. GDP per capita, 2017, Current US \$, https://data.wo rldbank.org/indicator/ny.gdp.pcap.cd.

31. GRAHAM B., MILLER M., STROM K., 2017, Safeguarding Democracy: Powersharing and Democratic Survival, in: American Political Science Review, 111(4), p. 686-704. 
32. HECHTER M., 2000, Containing Nationalism, Oxford University Press, Oxford.

33. HIBBS D.A., 1973, Mass Political Violence, Wiley, New York.

34. JACOBSEN J., 2015, Revisiting the Modernization Hypothesis: Longevity and Democracy, in: World Development, 67, p. 174-185.

35. KOZLOVSKYI S. V., 2010,. Economic policy as a basic element for the mechanism of managing development factors in contemporary economic systems, in: Actual Problems of Economics, 1(103), p. 1320.

36. KOZLOVSKYI S., MAZUR H., VDOVENKO N., SHEPEL T., KOZLOVSKYI V., 2018, Modeling and forecasting the level of state stimulation of agricultural production in Ukraine based on the theory of fuzzy logic, in: Montenegrin Journal of Economics, 14(3), p. 37-53.

37. KOZIUK V., DLUHOPOLSKYI O., PETRUK V., 2019, Globalization, innovation and fragility of optimal fiscal zones: secessions risks of Belgium, lessons for Ukraine, in: The Ideology and Politics Journal (Secessionisms in Europe: Societies, Political Systems and International Order under Stress), 1(12), p. 60-90.

38. KOZIUK V., DLUHOPOLSKYI O., 2018, Resource Curse: The Role of Weak Institutions and Crony-Sectors, in: The Ideology and Politics Journal (Post-Soviet Transit and Demodernization), 1(9), p. 68-102.

39. KOZIUK V., DLUHOPOLSKYI O., HAYDA Y., SHIMANSKA O., 2018, Typology of welfare states: quality criteria for governance and ecology, in: Problems and Perspectives in Management, 6(4), p. 235245.

DOI: $10.21511 / p p m .16(4) .2018 .20$

40. LIJPHART A., 1977, Democracy in Plural Societies: a Comparative Exploration, Yale University Press, New Heaven.

41. LIPSET S., 1959, Some Social Requisites of Democracy: Economic Development and Political Legitimacy, in: American Political Science Review, 53(1), p. $69-105$.

42. MAURO P., 1995, Corruption and Growth, in: Quarterly Journal of Economics, 110(3), p. 681-712.

43. MCCARTHY J.D., ZALD M.N., 1973, The Trend of Social Movements In America: Professionalization and Resource Mobilization, General Leading Press, Morristown NJ.

44. MINAEVA E., PANOV P., 2017, Ethnic regional autonomies: variation of the correlation between substate boundaries and ethnic groups' settlements, in: Political science, 4, p. 178-205.

45. NORTH D.C., WALLIS J.J., WEINGAST B.R., 2009, Violence and Social Orders: a Conceptual Framework for Interpreting Recorded Human History, Cambridge University Press, Cambridge.

46. OLSON M., 1965, The Logic of Collective Action: Public Goods and the Theory of Groups, Harvard University Press, Cambridge MA.

47. PAXTON P., 2002, Social Capital and Democracy: An Interdependent Relationship, in: American Sociological Review, 67(2), p. 254-277.

48. PIETERSE E., OLDFIELD S., 2002, Political Opportunity Structures of Urban Social Movements in South Africa, University of Cape Town Notes Prepared for Workshop on Social Movements in the South, Center of International Affairs. Harvard University, 17-20 May 2002, p. 1-10, Harvard University Press, Cambridge.

49. PRZEWORSKI A., 2005, Democracy as an Equilibrium, in: Public Choice, 123(3-4), p. 253-273.

50. ROEDER P., 2014, Secessionism, institutions, and change, in: Ethnopolitics, 13(1), p. 86-104.

51. ROTBERG R.I., 2004, When States Fail: Causes and Consequences, Princenton University Press, Princenton.

52. TAYLOR C., HUDSON M.C., 1972,. The World Handbook of Political and Social Indicators, Yale University Press, New Heaven.

53. THE WORLDWIDE GOVERNANCE INDICATORS (WGI) PROJECT, Interactive data access, http://info.worldbank.org/governance/wgi/\#reports.

54. TILly Ch., TARROW S., 2006, Contentious Politics, Paradigm Publishers, Boulder.

55. YOUSUF A., HADDAD H., PAKURAR M., KOZLOVSKYI S., MOHYLOVA A., SHLAPAK O., JANOS F., 2019, The effect of operational flexibility on performance: a field study on small and mediumsized industrial companies in Jordan, in: Montenegrin Journal of Economics, 15(1), p. 47-60.

56. WOLFF S., 2010, Approaches to conflict resolution in divided societies, in: Ethnopolitics Papers, 5. 